\title{
ASSESSMENT OF MINED SOILS IN EROSION-DEGRADED FARMLANDS IN SOUTH-EASTERN NIGERIA
}

\author{
Avaliação do solo em terras férteis degradadas por \\ erosão no sudoeste da Nigéria
}

Emmanuel UzomaOnweremadu

\section{Abstract}

This study assessed degradation status of erosion devastated soils as well as ameliorative measures on such soils. Field sampling was aided by morphological landscape changes. Surface samples $(0-20 \mathrm{~cm})$ depth were randomly collected from two erosion units and used in conducting a greenhouse experiment using maize (Zea mays $L$.) as a test crop. The experiment was laid out in a completely randomized design (CRD) and rates of ground periwinkle shells (GPS) and sewage sludge (SS) used as treatment. Treatments were replicated 9 times. Statistical tests of difference in soil properties were performed using t-statistic at $\mathrm{p}<0.05$. Status of soil degradation was evaluated using Land Degradation Index (LDI). Results showed low organic carbon content, and high bulk density and aggregate instability in eroded soils. The LDI values were high in most of physical parameters. The GPS and SS treatments significantly $(p<0.05)$ improved yield and soil properties except soil $\mathrm{pH}$ and aluminium saturation.

Keywords: Degradation; Soil amendment; Soil erosion; Soil mining; Soil properties.

\section{Resumo}

Esse estudo avaliou a situação da degradação, por erosão, de solos esgotados, bem como medidas para sua recuperação. Parte dessas áreas erodidas foi recuperada por meio de mudanças no perfil morfológico do solo. Amostras da superfície $(0-20 \mathrm{~cm})$ foram coletadas randomicamente, de duas regiões erodidas, e usadas em um experimento, numa casa de vegetação, com milho (Zea mays L.). O experimento foi desenvolvido totalmente ao acaso. Para ajudar a recuperação, restos de conchas de moluscos terrestres (CMT) mais lodo de esgoto (LE) foram usados como complementos para o tratamento da amostra de solo erodido. Nos experimentos (repetidos 9 vezes), o teste-t $(p<0,05)$ foi utilizado para a avaliação estatística. Também foi utilizado o Índice de Degradação de Solo (IDS) para verificar o estado deste. Os resultados mostraram baixa quantidade de carbono, alta densidade e instabilidade da massa de agregados dos solos analisados. Os valores de IDS eram altos na maioria dos parâmetros físicos. Os tratamentos com CMT e LE melhoraram significativamente $(p<0,05)$ a produção e as propriedades do solo, exceto o pH e a saturação de alumínio.

Palavras-chave: Degradação; Correção de solos; Erosão do solo; Infiltração de solos; Propriedades do solo.

Dr. Emmanuel Uzona Onweremadu, Soil Survey and Environment, Departament of Soil Science and Technology, Federal University of Tecnology, P.M.B. 1526 Owerri, Nigeria. e-mail: uzomaonweremadu@yahoo.com 


\section{Introduction}

Agriculture is a soil-based industry that extracts nutrients from the soil. Because soils are the storehouse of most plant nutrients continual withdrawals from them by continuous cropping practices without equivalent soil regenerating inputs endanger resource sustainability. An alarming concept that African soils are steadily depleted of nutrients due to farming without fertilizers has gained wide credence in the scientific community (1). As these soils become non-productive and vulnerable to natural agents of degradation, farmers still continue to cultivate on them, even expand to available and poorer non-farmlands in order to meet their basic food needs. This situation become worse in African as her population increased from an average of $2.5 \%$ in the 1960 s to more than $3 \%$ in the 1990 s (2).

The story of soil degradation by water erosion is topical in southeastern Nigeria (3). In this region, harsh climate, especially high intensity and long duration rainfall, high population density, land tenure constraints, shortened fallow periods, overgrazing and inefficiency of the traditional soil management practices have reduced the productive potentials of soils. The increasing farming population of the area cultivate even on fragile slope soils without appropriate conservation technology. As soils are not yielding to satisfy their basic needs, they resort to cutting down trees for fuelwood for economic gains as well as for domestic use in cooking as petroleum products are unaffordable given their socio-economic status. All these practices do not match soil quality and land use.

Several techniques and approaches are suggested in the evaluation of soil quality particularly as it affects soil degradation. Some authors evaluate decline in agricultural productivity in terms of fertilizer input, water management and tillage methods (4). Others use the soil quality morphological index (SQMI) to assess soil quality of near-surface soil physical properties (5). Again, criteria such as land use, management, prevalent weather, relative or comparative degradation, reversible and irreversible degradation indices have been suggested for the assessment of effects of degradation in terms of agricultural productivity (6). The degradative effects of soil mining due to continuous cultivation was evaluated using Land Degradation Index (7). In this technique, status of soil properties in less degraded soils are compared with values of the same properties in adjacent highly degraded sites. Levels of soil degradation are ascertained by observation of morphological variabilities of farmlands. Such morphological attributes include soil colour, soil drainage soil texture, soil structure, rupture resistance and other properties. The major objective of this study was to investigate the status of soil degradation in nutrient-mined soils of Southeastern Nigeria using Land Degradation Index (LDI). Specifically, the study evaluated the effect of different rates of ground periwinkle shells and sewage sludge in restoring degraded soils of the study area.

\section{Materials and metbods}

\section{Site description}

Southeastern Nigeria lies between latitudes $4^{\circ} 15^{1}$ and $7^{\circ} 00^{1} \mathrm{~N}$ and longitudes $5^{\circ} 51^{1}$ and $9^{\circ} 30^{1} \mathrm{E}$. Soils are derived from 6 major parent materials, namely alluvium, coastal plain sands, shale, lower coal measures, upper coal measures and falsebedded sandstones. Soils are highly weathered and over $70 \%$ belong to the order ultisols. It has a humid tropical climate with the southernmost part of the agroecology having udic moisture regime when compared with the ustic nature of the northern fringes of the area. Annual rainfall ranges from 1750 to over $2500 \mathrm{~mm}$. Mean annual temperature ranges from $26^{\circ} \mathrm{C}\left(78^{\circ} \mathrm{F}\right)$ to $28^{\circ} \mathrm{C}$ $\left(82^{\circ} \mathrm{F}\right)$ or hotter. Cuesta and scarped landscapes and gentle to undulating lowland area are characteristic of the site. Soils in the study area have multiple uses ranging from agriculture, forestry, mining, waste disposal and constructions. Land use is not planned. Climate population density and poverty interact to cause land degradation.

\section{Field studies}

Four maps, namely geological, geomorphological, hydrological and land use maps were superimposed to create homogenous study units. The study area covers about $13032 \mathrm{~km}^{2}$ and soils were delineated from the same parent material (Coastal Plain Sands). Four sampling units were identified as Mbaise, Umuahia, Akwette and Oguta and their geographical coordinates are given on Table 1. Geographical coordinates were obtained using Handheld Global Positioning System (GPS) Receiver (Garmin Ltd, Kansas, USA). Macromorphological features are shown 
on Table 1. In each sampling unit, an eroded farmland and its adjacent uneroded farmland were chosen for the study. These two farmlands were considered similar in many edaphological features but intensity of water erosion. These sampling units were identified assisted by village informants and were randomly chosen as there existed several other similar units in the area.

Fifty topsoil samples were collected from each subsampling unit (eroded or uneroded) and from the four sampling units, giving a total of 200 soil samples for eroded and 200 soil samples for uneroded units. Undisturbed cores (diameter, $15 \mathrm{~cm}$; length, $15-20 \mathrm{~cm}$ were excavated from the surface horizon (Ap). The column of soil encased in the polyvinyl chloride pipe (diameter, $15 \mathrm{~cm}$ ) was trimmed at the base, packed, and transported to the laboratory for relevant determinations. Soil samples were collected at $0-20 \mathrm{~cm}$ depth (Ap horizon). These soil samples were air-dried, crushed and sieved using $2 \mathrm{~mm}$ sieve. Soils of the sampling units were classified as Ultisols (Acrisols) (8).

\section{Greenbouse studies}

Differences in productivity potentials of different rates of amendments on soil samples collected from uneroded and eroded portions of owner-managed farmlands were assessed by comparing yields obtained using maize (Zea mays L.) as indicator crop. Maize variety used was 8329-22.

In the greenhouse study, bulked soil samples collected from Ap horizon (0-20 cm depth) in each sampling unit of the study site were maintained at field capacity ( $20 \%$ gravimetric moisture content) and planted with maize in a Completely Randomized Design (CRD) with each treatment replicated 9 times. The maize grain yield was harvested and recorded at maturity.

\section{Laboratory analysis}

Bulk density was measured by core method of Grossman and Reinsch (2002) (9). In the laboratory, the polyvinyl chloride casing was carefully removed from each column. Therefore, each column was coated with 5 - to $8-\mathrm{mm}$ layer of liquid paraffin to seal the column walls against side flow and creation of crevices between the wall of the casing and the soil. This approach would equally circumvent possible overestimation of saturated hydraulic conductivity
(Ksat) in each column. The soil column were slowly welted from the bottom. After the wetting process, two $10-\mathrm{cm}$ stainless steel probes were inserted horizontally to monitor volumetric water content by using time domain reflectometry (10). Saturation hydraulic conductivity (Ksat) was determined using the constant-head method (11) and $0.025 \mathrm{~mol} \mathrm{~L}^{-1}$ of KNO3 solution was used to minimize clay dispersion. Soil water-holding capacity was measured on undisturbed samples as the difference of water contents at $-0.03 \mathrm{MPa}$, determined by pressure plate, and at $-1.5 \mathrm{MPa}$, determined by pressure membrane (12). Total porosity was estimated from bulk density using an assumed bulk density of $2.65 \mathrm{Mgm}^{-3}$ while macro-porosity (MP) was calculated as the ratio of volume of water drained at $60 \mathrm{~cm}$ tension to the volume of the bulk soil used (13). Aggregate instability was estimated as the number of water droplets required to break a ped.

After equilibrating for 30 minutes, soil $\mathrm{pH}$ was determined in $0.1 \mathrm{~N} \mathrm{KCl}$ solution, with a soilliquid ratio of 1:2.5 using a Beckman Zeromatic $\mathrm{pH}$ meter (9). Soil organic carbon, total nitrogen, and available phosphorus were measured by wet oxidation $(14,15)$, micro-kjeldahl (16) and bicarbonate techniques (17). Exchangeable basic cations were determined by the method of the Association of Official Analytical Chemists (18) while exchangeable acidity was measured titrimentically.

\section{Calculation}

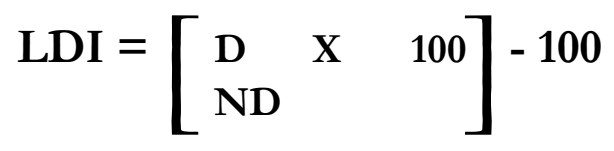

Land degradation index (LDI) was computed as follows:
Where
$\mathrm{D}=$ degraded value of selected parameter
$\mathrm{ND}=$ non-degraded value of selected parameter
$100 \%=$ percentage grade
$100=$ constant representing ideal soil state.

Negative values indicate degradation while otherwise show movement in parameter values. 


\section{Statistical analyses}

Statistical tests of difference of selected soil properties were performed using $\mathrm{t}-$ statistic at $5 \%$ level of probability.

\section{Results and discussion}

\section{Macromorphological}

Table 1 shows results of macromorphological studies of the site. Soils were sandy and well-drained. Uneroded soils were very dark to dark brown while eroded soils were dark gray to yellowish red while sandiness is attributable to nature of parent materials, soil colour variability was in response to differential removal of organic materials by runoff water from the Ap horizon. Although soil colour is scarcely used as an indicator of soil fertility reliable extrapolations from colour of these soils can be used to predict soil quality. Grade of soil structure indicates moderate to strong structure (uneroded soils) while structureless to weak soil structures predominated in eroded soils. Similar findings were made in earlier studies in the region (19). They attributed poor soil structure at topsoils to low organic carbon content leading to macro-aggregate instability.

\section{TABLE 1 - Macromorphological features of study site (Ap horizon)}

\begin{tabular}{|c|c|c|c|c|c|c|c|c|}
\hline Location & Depth $(\mathrm{cm})$ & Colour (moist) & Texture (feel) & Structure & Grade & Consistence (moist) & Drainage & Geographical coordimates \\
\hline \multicolumn{9}{|l|}{ Mbaise } \\
\hline Uneroded & $0-20$ & OB 10 YR $3 / 3$ & SL & 2 & $2 \%$ & $\mathrm{mfr}$ & WD & $5^{\circ} 48^{1} 33^{11} \cdot 010^{\circ} \mathrm{N}$ \\
\hline Eroded & $0-10$ & YB 10 YR 5/6 & LS & 0 & & $\mathrm{ml}$ & WD & $\begin{array}{l}7^{\circ} 37^{1} 10^{11} \cdot 040^{\circ} \mathrm{E} \\
60 \mathrm{~m}(\mathrm{Z})\end{array}$ \\
\hline \multicolumn{9}{|l|}{ Umuahia } \\
\hline Uneroded & $0-20$ & $\begin{array}{l}\text { VDB } 10 \text { YR } \\
2 / 2\end{array}$ & SL & 2 & $2 \%$ & $\mathrm{mfi}$ & WD & $5^{\circ} 47^{1} 58^{11} \cdot 047 \mathrm{~N}$ \\
\hline Eroded & $0-13$ & YB 10 YR 5/4 & SL & 0 & & $\mathrm{ml}$ & WD & $\begin{array}{l}7^{\circ} 37^{1} 26^{11} \cdot 120 \mathrm{E} \\
95 \mathrm{~m}(\mathrm{Z})\end{array}$ \\
\hline \multicolumn{9}{|l|}{ Akwette } \\
\hline Uneroded & $0-22$ & DB 7.5YR $3 / 2$ & SL & 3 & $2 \%$ & $\mathrm{mfi}$ & WD & $5^{\circ} 3^{1} 13^{11} \cdot 450 \mathrm{~N}$ \\
\hline Eroded & $0-14$ & DG 10YR 4/1 & SL & 1 & & $\mathrm{mfr}$ & PD & $\begin{array}{l}7^{\circ} 39^{1} 45^{11} \cdot 310 \mathrm{E} \\
48 \mathrm{~m}(\mathrm{Z})\end{array}$ \\
\hline \multicolumn{9}{|l|}{ Oguta } \\
\hline Uneroded & $0-24$ & $\begin{array}{l}\text { VSB } 7.5 \text { YR } \\
2 / 2\end{array}$ & SL & 3 & $2 \%$ & $\mathrm{mfi}$ & WD & $5^{\circ} 53^{1} 16^{11} \cdot 148 \mathrm{~N}$ \\
\hline Eroded & $0-14$ & YB 10YR 5/8 & SL & 1 & & $\mathrm{mfr}$ & PD & $\begin{array}{l}7^{\circ} 20^{1} 32^{11} \cdot 40^{\circ} \mathrm{E} \\
50 \mathrm{~m}(\mathrm{Z})\end{array}$ \\
\hline
\end{tabular}

Colour: $\mathrm{VDB}=$ very dark brown, $\mathrm{DG}=$ dark gray, $\mathrm{YB}=$ Yellowish brown, $\mathrm{YR}=$ Yellowish red

Texture: $\mathrm{LS}=$ loamy sand, $\mathrm{SL}=$ sandy loam

Structure: $\mathrm{O}=$ structureless, $1=$ weak, $2=$ moderate, $3=$ strong

Consistence: $\mathrm{ml}=$ loose, $\mathrm{mfr}=$ friable, $\mathrm{mfi}=$ firm

Drainage: wd $=$ well-drained, $\mathrm{PD}=$ poorly drained

Geographical coordinates: $Z=$ altitude.

Water erosion-induced discernable changes in soil properties, especially in physical attributes. Changes in soil physical properties resulting from water erosion are presented in Table 2 . With the exception of bulk density and aggregate instability, values of all physical parameter measured were higher in uneroded units of farmland. Increases bulk in density with consequent reduction in total porosity, macroporosity and saturated hydraulic conductivity has been reported (20). These lead to reduction in infiltration capacity and total available water capacity of soils. Aggregate instability values were higher in eroded soils possibly due to loss of binding agents to the erosive runoff. 
Assessment of mined soils in erosion-degraded farmlands in south-eastern Nigeria

TABLE 2-Changes in some physical properties of an ultisol (Acrisol) induced by water erosion (APhorizon)

\begin{tabular}{|c|c|c|c|c|c|c|c|c|c|}
\hline \multirow[b]{2}{*}{ Property } & \multirow[b]{2}{*}{ Unit } & \multicolumn{2}{|c|}{ Mbaise } & \multicolumn{2}{|c|}{ Umuahia } & \multicolumn{2}{|c|}{ Akwette } & \multicolumn{2}{|c|}{ Oguta } \\
\hline & & Uneroded & Eroded & Uneroded & Eroded & Uneroded & Eroded & Uneroded & Eroded \\
\hline Bulk density (BD) & $\mathrm{Mg} \mathrm{m}^{-1}$ & 1.19 & 1.68 & 1.21 & 1.65 & 1.16 & 1.61 & 1.25 & 1.56 \\
\hline Total porosity (TP) & $\%$ & 55.09 & 36.60 & 54.33 & 37.73 & 56.23 & 39.25 & 52.83 & 41.13 \\
\hline $\begin{array}{l}\text { Macroporosity (Ma.P) } \\
\text { Water retained@ }\end{array}$ & $\%$ & 32.26 & 18.13 & 31.06 & 17.92 & 30.24 & 17.66 & 29.18 & 15.77 \\
\hline $\begin{array}{l}\text { Water retained @ } \\
-0.3\end{array}$ & $\mathrm{MPa}$ & 56.12 & 41,23 & & 4216 & 6235 & 5038 & 5552 & 3963 \\
\hline-15 & $\mathrm{MPa}$ & 25.03 & 28.01 & 24.26 & $\begin{array}{l}42.10 \\
25.81\end{array}$ & 28.21 & 33.06 & $\begin{array}{l}53.02 \\
27.82\end{array}$ & 29.11 \\
\hline $\begin{array}{l}\text { Total Available water } \\
\text { (TAW) }\end{array}$ & $\%$ & 31.09 & 13.22 & 32.92 & 16.35 & 34.14 & 17.32 & 27.70 & 10.52 \\
\hline Saturation hydraulic & & & & & & & & & \\
\hline Conductivity (K & $\mathrm{Cmsec}^{-1}$ & 0.084 & 0.037 & 0.88 & 0.036 & 0.087 & 0.040 & 0.92 & 0.42 \\
\hline Aggregate instability & & 0.116 & 0.215 & 0.119 & 0.218 & 0.119 & 0.228 & 0.121 & 0.231 \\
\hline
\end{tabular}

$*=$ Number of water drops required to break a ped.

Adverse changes in soil chemical properties were observed (Table 3 ) following water erosion of farmlands. Reduced $\mathrm{pH}$ and increased aluminium saturation of studies eroded soils suggest unfavourable chemical changes which impair the over all fertility status of farmlands. With substantial proportion of its occupation of cation exchange site, high Al (Aluminium saturation $=54-68 \%$ ) in eroded soils at low soil $\mathrm{pH}$ it suggests unavailability of plant essential nutrients at optimal levels. The $\mathrm{pH}$ range $(\mathrm{pH}=3.7-$ 4.9 ) is limiting to plant performance and may cause aluminium toxicity although this depends on the species of aluminium (21). Aluminium in solution forms hydroxyl - Al polymers, ion pairs with anions, and complexes with organic substances and such complexation renders aluminium ions non-toxic. However, low organic matter content of eroded soils $(\mathrm{OM}=1.1-1.4 \%)$ may be suggesting poor influence of organic matter in detoxifying aluminium in these highly weathered soils of the tropics. These low $\mathrm{pH}$ and organic matter values could be responsible for the lower available phosphorus in eroded soils (Available $\left.\mathrm{P}=8.3-10.1 \mathrm{mg} \mathrm{kg}^{-1}\right)$. Again, soil $\mathrm{P}$ is lost through surface runoff, erosion of sediment, leaching and plant uptake (22). These losses endanger the environment to non-point-source pollution, such as eutrophication.

\section{TABLE 3 - Changes in chemical properties in an ultisol Acrisol in southeastern Nigeria induced by water erosion (Ap horizon) (mean values)}

\begin{tabular}{|c|c|c|c|c|c|c|c|c|c|}
\hline & \multirow[b]{2}{*}{ Unit } & \multicolumn{2}{|c|}{ Mbaise } & \multicolumn{2}{|c|}{ Umuahia } & \multicolumn{2}{|c|}{ Akwette } & \multicolumn{2}{|c|}{ Oguta } \\
\hline & & Uneroded & Eroded & Uneroded & Eroded & Uneroded & Eroded & Uneroded & Eroded \\
\hline $\mathrm{pH}(\mathrm{KCl})$ & - & 4.3 & 3.7 & 5.0 & 4.1 & 4.9 & 3.9 & 5.2 & 4.6 \\
\hline ECEC & $\mathrm{cmol} \mathrm{kg}^{-1}$ & 10.8 & 5.6 & 12.1 & 6.3 & 11.2 & 6.6 & 13.2 & 7.0 \\
\hline Base saturation & $\%$ & 56.6 & 38.9 & 58.0 & 4.0 & 57.8 & 42.0 & 60.0 & 32 \\
\hline Aluminium saturation & $\%$ & 43.4 & 61.1 & 42.0 & 54.0 & 42.2 & 57.0 & 40.0 & 6.8 \\
\hline Organic matter & $\%$ & 3.2 & 1.1 & 3.3 & 1.5 & 3.6 & 1.4 & 3.5 & 1.3 \\
\hline Total nitrogen & $\%$ & 0.28 & 0.09 & 0.29 & 0.11 & 0.3 & 0.1 & 0.3 & 1.1 \\
\hline
\end{tabular}

ECEC: Effective cation exchange capacity.

\section{Soil degradation}

Table 4 shows land degradation index values of these mined and eroded soils as they affect soil physical properties. Water retained at $1.5 \mathrm{MPa}$ and aggregate instability increased in value which implies loss of available water in the rhizosphore and soil structural breakdown respectively. There were outstanding degradation in bulk density (LDI mean = -60 ), total porosity (LDI mean $=-71$ ), macroporosity $($ LDI mean $=-56)$ and water retained at $0.1 \mathrm{MPa}$ $($ LDI mean $=-75)$ and these reduced saturated hydraulic conductivity $($ LDI mean $=-25)$ and total available water $($ LDI mean $=-45)$. 


\section{TABLE 4 - Land degradation index values of mined and eroded sites (physical properties)}

\begin{tabular}{|c|c|c|c|c|c|c|c|c|}
\hline \multicolumn{9}{|l|}{ Property } \\
\hline Location & $\mathrm{BD}$ & TP & MaP & $\begin{array}{l}\text { Water retained } \\
0.1 \mathrm{MPa}\end{array}$ & $\begin{array}{l}\text { Water retained } \\
1.5 \mathrm{MPa}\end{array}$ & TAW & Ksat & $\begin{array}{l}\text { Agg. } \\
\text { Inst. }\end{array}$ \\
\hline Mbaise & -41 & -66 & -56 & -73 & +11 & -42 & -44 & +15 \\
\hline Umuahia & -63 & -69 & -57 & -74 & +55 & -49 & -4 & +17 \\
\hline Akwette & -61 & -70 & -58 & -80 & +17 & -51 & -46 & +9 \\
\hline Oguta & -75 & -78 & -54 & -71 & +5 & -38 & -5 & +10 \\
\hline Mean & -60 & -71 & -56 & -75 & +40 & -45 & -25 & +13 \\
\hline
\end{tabular}

Agg. Inst. = aggregate instability.

Soil chemical properties were also degraded (Table 5) with base saturation and soil pH having highest LDI mean values of -68 and -63 respectively.

\section{TABLE 5 - Land degradation index values of mined and eroded sites (chemical properties)}

\begin{tabular}{llllllll}
\hline Location & $\mathrm{pH}$ & $\mathrm{ECEC}$ & Bsat & Alsat & OM & TN & Avail. P \\
\hline Mbaise & -77 & -52 & -68 & +59 & -34 & -32 & -45 \\
Umuahia & -82 & -52 & -79 & +71 & -45 & -38 & -53 \\
Akwette & -79 & -59 & -74 & +65 & -39 & -33 & -36 \\
Oguta & -88 & -55 & -53 & +30 & -37 & -33 & -50 \\
Mean & -63 & -55 & -68 & +54 & -36 & -34 & -46 \\
\hline
\end{tabular}

$\mathrm{ECEC}=$ effective cation exchange capacity, $\mathrm{Bsat}=$ base saturation, Alsat $=$ aluminium saturation, $\mathrm{OM}=$ organic matter, T.N = total nitrogen, Avail. $\mathrm{P}=$ available phosphorus .

These degradations in both physical and chemical properties of soils influence overall productivity of soils and responses of even inorganic fertilizers when applied on eroded lands. This is worst under soil physical infertility thus the call for integration of organic and inorganic fertilization as a low-cost technology for restoring and sustaining mined and eroded soils of southeastern Nigeria (23). It is also implied that these degradations eventually affect microand macro-organisms as their activities reduced following soil loss (24), suggesting negative effects on the elemental transformations within the soil system.

\section{Effects of amendments on maize yield}

Table 6 indicates yield responses of maize (Zea mays L.) following application of different rates of ground periwinkle shells (GPS) and sewage sludge (SS). A mixture of GPS and SS significantly $(p<0.05)$ improved yield probably due to liming effect and nutrient increase in treated soils. Ground periwinkle shells released high amount of calcium which deacidified soils, and consequent release of fixed nutrients while transformation of sewage sludge resulted in additions of nutrients. 


\section{TABLE 6-Effectiveness of ground periwinkle shell/sewage sludgle mixture in restoring productivity of mined and eroded soils in southeastern Nigeria using maize test as $\operatorname{crop}\left(t h a^{-1}\right)$}

\begin{tabular}{|c|c|c|c|c|c|c|c|c|c|c|c|c|}
\hline & \multicolumn{3}{|c|}{ Mbaise } & \multicolumn{3}{|c|}{ Umuahia } & \multicolumn{2}{|c|}{ Akwette } & \multicolumn{4}{|c|}{ Oquta } \\
\hline Rate of amendment & Uneroded & Eroded & t-cal & Uneroded 1.92 & Eroded & t-cal & Uneroded & Eroded & t-cal & Uneroded & Eroded & t-cal \\
\hline $\mathrm{GPS}_{0} \mathrm{SS}_{0}$ & 0.32 & 0.26 & $0.8 \mathrm{NS}$ & 1.92 & 1.16 & NS & 3.22 & 2.82 & NS & 3.01 & 2.24 & $0.1 \mathrm{NS}$ \\
\hline $\mathrm{GPS}_{60} \mathrm{SS}_{150}$ & 2.98 & 0.62 & $0.2^{*}$ & 3.08 & 1.11 & $0.5^{\star}$ & 3.76 & 1.98 & $0.5^{\star}$ & 4.16 & 2.46 & $0.7^{\star}$ \\
\hline $\mathrm{GPS}_{120} \mathrm{SS}_{300}$ & 3.16 & 0.89 & $0.5^{\star}$ & 3.67 & 2.36 & $0.6^{*}$ & 4.92 & 2.13 & $0.6^{*}$ & 4.96 & 2.66 & $0.7^{\star * *}$ \\
\hline $\mathrm{GPS}_{240} \mathrm{SS}_{600}$ & 3.72 & 2.06 & $0.6^{* *}$ & 3.06 & 2.68 & $0.7^{*}$ & 4.02 & 2.81 & $0.7^{\star}$ & 4.93 & 2.76 & $0.7^{\star}$ \\
\hline
\end{tabular}

$\mathrm{t}$-cal ** significant at $\mathrm{P}<0.01, *$ significant at $\mathrm{P}<0.05$, NS not significant.

numerical subscripts under rate of amendment refer to rates of ground periwinkle shell (GPS) and sewage sludge (SS) measured in $\mathrm{kg} \mathrm{ha}^{-1}$.

\section{Post-harvest changes in soil roperties}

Results of post-harvest soil tests are shown in Table 7 (physical properties) and Table 8 (chemical properties). There were significant changes $(p<0.05)$ in most soil properties with the exception of $\mathrm{pH}$ and aluminium saturation (Table 9). Insignificant changes in soil $\mathrm{pH}$ could be attributed to dissociation of weakly bonded hydrogen ions of amino and phenolic groups present in sewage-sourced organic matter and their consequent release into the soil system.

\section{TABLE 7-Post-harvest changes in soil physical properties in ultisols (Acrisols) Nigeria induced by soil amendment}

\begin{tabular}{|c|c|c|c|c|c|c|c|c|}
\hline $\begin{array}{l}\text { Rate of } \\
\text { application }\end{array}$ & $\mathrm{BD}\left(\mathrm{Mgm}^{-1}\right)$ & TP (\%) & $\begin{array}{l}\mathrm{MaP} \\
(\%)\end{array}$ & $\begin{array}{l}\text { Water retained at } \\
0.1(\mathrm{MPa})\end{array}$ & $\begin{array}{l}\text { Water retained } \\
\text { at } 1.5(\mathrm{MPa})\end{array}$ & TAW (\%) & $\begin{array}{l}\text { Ksat } \\
\left(\mathrm{cmsec}^{-1}\right)\end{array}$ & Agg. Int. $\left(\mathrm{N}^{-1}\right)$ \\
\hline $\mathrm{GPS}_{\mathrm{O}} \mathrm{SS}_{0}$ & 1.71 & 35.0 & 28.34 & 40.6 & 29.5 & 11.1 & 0.35 & 0.315 \\
\hline $\mathrm{GPS}_{60} \mathrm{SS}_{150}$ & 1.58 & 40.0 & 34.23 & 52.0 & 25.0 & 27.0 & 0.52 & 0.208 \\
\hline $\mathrm{GPS}_{120} \mathrm{SS}_{300}$ & 1.46 & 44.0 & 37.41 & 54.5 & 24.1 & 30.4 & 0.66 & 0.113 \\
\hline $\mathrm{Gps}_{180} \mathrm{SS}_{450}$ & 1.41 & 46.0 & 37.88 & 56.1 & 28.1 & 33.0 & 0.86 & 0.104 \\
\hline $\mathrm{GPS}_{240} \mathrm{SS}_{600}$ & 1.40 & 47.2 & 38.14 & 56.8 & 23.7 & 33.1 & 0.96 & 0.093 \\
\hline
\end{tabular}

\section{TABLE 8 - Post-harvest changes in soil chemical properties in ultisols (Acrisols) in southeastern Nigeria induced by soil amendment}

\begin{tabular}{lllllllr}
\hline Rate of application & $\begin{array}{l}\mathrm{pH} \\
(\mathrm{KCl})\end{array}$ & $\begin{array}{l}\text { ECEC } \\
(\mathrm{cmol} \mathrm{kg})\end{array}$ & $\begin{array}{l}\text { Bsat } \\
(\%)\end{array}$ & $\begin{array}{l}\text { Alsat } \\
(\%)\end{array}$ & $\begin{array}{l}\text { OM } \\
(\%)\end{array}$ & $\begin{array}{l}\text { TN } \\
(\%)\end{array}$ & $\begin{array}{r}\text { Avail. P } \\
\left(\mathrm{mg} \mathrm{kg}^{-1}\right)\end{array}$ \\
\hline GPS $_{0} \mathrm{SS}_{0}$ & 3.5 & 5.3 & 33 & 67 & 1.2 & 0.09 & 6.8 \\
GPS $_{60} \mathrm{SS}_{150}$ & 3.9 & 8.7 & 39 & 61 & 1.8 & 0.16 & 8.8 \\
GPS $_{120} \mathrm{SS}_{300}$ & 4.6 & 10.8 & 45 & 55 & 2.1 & 0.18 & 11.6 \\
GPS $_{180} \mathrm{SS}_{450}$ & 4.9 & 13.4 & 48 & 52 & 2.7 & 0.22 & 15.6 \\
GPS $_{240}$ SS $_{600}$ & 5.4 & 14.5 & 52 & 48 & 2.9 & 0.25 & 14.8 \\
\hline
\end{tabular}


TABLE 9-Statiscal tests of difference of some soil properties in amended and non-amended soils

\begin{tabular}{ll}
\hline Soil properties & Calculated t-values \\
\hline Bulk density $\left(\mathrm{mgm}^{-3}\right)$ & $2.51^{\star}$ \\
Total available water $(\%)$ & $2.76^{\star}$ \\
Aggregate instability $\left(\mathrm{N}^{-1}\right)$ & $2.26^{\star}$ \\
Saturated hydraulic conductivity & $2.43^{\star}$ \\
pH & $1.67^{\mathrm{NS}}$ \\
ECEC (cmolkg-1) & $2.78^{\star}$ \\
Organic matter $(\%)$ & $2.88^{\star}$ \\
Alsaturation $(\%)$ & $1.48^{\mathrm{NS}}$ \\
Total nitrogen $(\%)$ & $2.82^{\star}$ \\
Available phosphorus $\left(\mathrm{mgkg}^{-1}\right)$ & $2.18^{\star}$ \\
\hline
\end{tabular}

* significant at $\mathrm{p}<0.05, \mathrm{NS}=$ not significant.

Organic matter $(\mathrm{OM})$ content increased in sewage-treated soils in line with earlier findings (25) that sewage application increased soil OM. The OM increases at different rates may be responsible for improvements in other soil properties, such as total available water bulk density, aggregation, hydraulic conductivity (saturation), total nitrogen, available phosphorus and effective cation exchange capacity (ECEC). Macroporosity increased with reducing aggregate instability in the amended soils leading to increase in saturated hydraulic conductivity. As longterm intensive cultivation without replenishment deteriorates organic matter and loss of productivity (26), addition of sewage sludge which is a major waste products in the study site will be beneficial in arable farming.

\section{References}

1. Bationo A, Lompo F, Koala S. Research on Nutrient Flows and Balances in West African: State of the Art. Agriculture, Ecosystems and Environment. 1998; 71:19-35.

2. Reich PF, Number ST, Almaraz RA, Eswaran H. Land Resource Stresses and Desertification in Africa. Agro-Science. 2001; 2(2):1-10.

3. Igwe CA. Soil Degradation Response to Soil Factors in Central Eastern Nigeria. In: Proceedings of the $28^{\text {th }}$ Annual Conference of Soil Science Society of Nigeria held at National Root Crops Research Institute. Umudike; 2003. Nigeria: 2003. 4-7 Nov. p. 228-234.
4. Mbagwu JSC, Obi ME. Land Degradation, Agricultural Productivity and Rural Poverty: Environmental Implications. In: Proceedings of the $28^{\text {th }}$ Annual Conference of Soil Science Society of Nigeria held at National Root Crops Research Institute Umudike; 2003; Nigeria: 2003; 4-7 Nov, p. 1-11.

5. Seybold CA, Grossman RB, Hoper H, Muckel G, Karlen DL. Soil Quality Morphological Index Measured in the 1996 NRI Pilot Study. Soil Survey Horizon. 2004; 45:86-95.

6. Lal R. Soil Quality and Sustainability. In: Lal R, Blum WEH, C. Valentine C,Stewart BA, editores. Methods of Assessment of Soil Degradation. Adv. Soil Sci. New York: CRC Press; 1997. p. 17-30.

7. Barrow CJ. Land Degradation. New York: Cambridge University Press; 1992.

8. Onweremadu EU. Application of Geographic Information Systems (GIS) on Soils, Land Use and Soil-related Environmental Problems in Southeastern Nigeria. Unpublished Ph.D Thesis of the University of Nigeria Nsukka. 2006; 472.

9. Grossman RB, Reinsch TG. Bulk Density and Linear Extensibility. In: Dane JH,Topp GC, editor. Methods of Soil Analysis. Physical Methods. Soil Science Society America Book Series. ASA and SSSA, WI. 2002; (5 Pt. 4):201-228.

10. Carlan WL, Perkins HF, Leonard RA. Movement of Water in a Plinthic Paleudult using a Bromide Tracer. Soil Science. 1985;139:62-66. 
Assessment of mined soils in erosion-degraded farmlands in south-eastern Nigeria

11. Klute A, Dirksen C. Hydraulic Conductivity and Diffusivity:Laboratory Methods. In: Klute S editor. Methods of Soil Analysis. $2^{\text {nd }}$ edition. Agron Monogr Madison, WI. 1986; (9 Pt. 1):687-732.

12. Dane JH, Hopmans JW. Water Retention and Storage: Laboratory Methods. In: J. H. Dane JH, Topp GC editor. Methods of Soil Analysis. Physical Methods. Soil Science Society America Book Series. ASA and SSSA, Madison, WI. 2002; (5 Pt. 4):675-720.

13. Nnaji GU, Asadu CLA, Mbagwu JSC. Evaluation of Physico-chemical Properties of Soils under Selected Agricultural Land Utilization Types. AgroScience. 2002; 3(1):27-33.

14. Maclean EO. Soil pH and Lime Requirement. In:Page AL,Miller RH,Keeney DR, editores. Methods of Soil Analysis. 2 ${ }^{\text {nd }}$ ed. Agronomy Monograph ASA and SSSA Madison WI. 1982; (9 Pt. 2):199-234.

15. Nelson DW, Sommers LE. Total Carbon, Organic Carbon, and Organic matter. In: AL. Page, RH. Miller, DR. Keeney, editores. Methods of Soil Analysis, $2^{\text {nd }}$ ed. Agronomy Monograph. ASA and SSSA, Madison, WI. 1982; (9 Pt. 2):539-579.

16. Bremner JM. Nitrogen-total. In: Sparks DL, editores. Methods of Soil Analysis, Chemical Methods. ASA and SSSA, Madison, WI. 1996; (5 Pt. 3):1085-1121.

17. OlsenSR, Sommers LE. Phosphorus. In: Page AL, Miller RH, and Keeney DR, editores. Methods of Soil Analysis, $2^{\text {nd }}$ ed. Agronomy Monograph. ASA and SSSA, Madison, WI. 1982; (9):403-430.

18. AOAC. Official Methods of Analysis, $15^{\text {th }}$ ed. Association of Official Analytical Chemists, Washington: D. C; 1990.
19. Igwe CA, Stahr K. Water-stable Aggregates of Flooded Inceptisols from Southeastern Nigeria in Relation to Mineralogy and Chemical Properties. Australian Journal of Soil Research. 2004; 42:171-197.

20. Mbagwu JSC. Erodibility of Soils formed on a Catenary Toposequence in Southern Nigeria as Evaluated by Different Indices. East African Agricultural and Forestry Journal. 1986; 52:74-80.

21. Gillman GP, Shamshuddin J, Bell LC. Soil Chemical Parameters and Organic Matter in Soil Management. Proceedings of a workshop organized by the International Board for Soil Research and Management (IBSRAM), Bangkok, Thailand. 1989; (8):141-153.

22. Zhang H, Schroder JL, Fuhrman JK, Basta NT, Storm DE, Payton ME. Path and Multiple Regression Analyses of Phosphorus Sorption Capacity. Soil Science Society America Journal. 2005; 69:96-106.

23. Agbim NN. Potentials of Cassava Peels as a Soil Amendment II Field Evaluation. Journal of Environment Quality. 1985;14:411-415.

24. Mbagwu JSC. Physico-chemical Properties and Productivity of an Ultisol in Nigeria as Affected by Longterm erosion. Pedelogie. 1988; 38:137-154.

25. Angers, Dayegamiye AN. Effects of Manure Application on Carbon, Nitrogen and Carbohydrate Contents of a Silt Loam and its Particle Size Fractions. Biological Fertility Soils. 1991;11:79-82.

26. Piovanelli C, Ceccherini MT, Castaldini M, Pagliai M, Miclaus N. Tillage Impact on Soil Quality: Biological Properties in Surface Soils. Italian Journal of Agronomy. 1998;1:21-27. 